\title{
The effects of pomegranate extract on anaerobic exercise performance \& cardiovascular responses
}

\author{
Erica J Roelofs', Katie R Hirsch, Eric T Trexler, Meredith G Mock, Abbie E Smith-Ryan \\ From The Twelfth International Society of Sports Nutrition (ISSN) Conference and Expo \\ Austin, TX, USA. 11-13 June 2015
}

\begin{abstract}
Background
During exercise, there is an increased demand for oxygen. Increasing blood flow may provide an ergogenic effect. Dietary nitrate supplementation, such as pomegranate extract (PE), has been linked to reduced vascular resistance, enhanced vasodilation, and increased blood flow to possibly improve exercise efficiency. The purpose of this study was to evaluate the effects of acute PE supplementation on anaerobic exercise, flow mediated dilation (FMD), oxygen saturation $\left(\mathrm{SPO}_{2}\right)$, heart rate ( $\left.\mathrm{HR}\right)$, and blood pressure (BP).
\end{abstract}

\section{Methods}

Nineteen recreationally active individuals (mean \pm SD; Age: $22.1 \pm 1.9$ yrs; Height: $170.4 \pm 12.4 \mathrm{~cm}$; Weight: $68.7 \pm 15.9 \mathrm{~kg}$ ) participated in this crossover design study. In a double-blind fashion, participants were randomized to either $1000 \mathrm{mg}$ of PE (True Pomegranate Extract, Stiebs Nature Elevated, Madera, CA) or placebo (PL; 95\% maltodextrin, $5 \%$ purple carrot and hibiscus for color), ingested in capsule form $30 \mathrm{~min}$ prior to a repeated sprint ability (RSA) test. Peak and average power were identified from the RSA on a friction-loaded cycle ergometer (Monark 894E, Stockholm, Sweden), which consisted of ten six-second maximal sprints with a load of $65 \mathrm{~g} / \mathrm{kg}$ of body weight with 30 seconds of passive recovery. Brachial artery FMD was assessed by ultrasound (GE logiq-e B-mode, GE Healthcare, WI) with vascular, pulse wave, and color flow settings to determine blood flow and vessel diameter. FMD, $\mathrm{HR}, \mathrm{SPO}_{2}$, and $\mathrm{BP}$ were assessed at baseline, $30 \mathrm{~min}$ post ingestion (30 minPI), immediately post exercise (IPost), and $30 \mathrm{~min}$ post exercise (30minPostEx). After a seven-day washout period, participants completed the RSA test with the opposite treatment. Separate two-way

* Correspondence: eroelofs@live.unc.edu

Applied Physiology Laboratory, University of North Carolina, Chapel Hill, NC, USA 
doi:10.1186/1550-2783-12-S1-P56

Cite this article as: Roelofs et al:: The effects of pomegranate extract on anaerobic exercise performance \& cardiovascular responses. Journal of

the International Society of Sports Nutrition 2015 12(Suppl 1):P56.

Submit your next manuscript to BioMed Central and take full advantage of:

- Convenient online submission

- Thorough peer review

- No space constraints or color figure charges

- Immediate publication on acceptance

- Inclusion in PubMed, CAS, Scopus and Google Scholar

- Research which is freely available for redistribution

Submit your manuscript at www.biomedcentral.com/submit
C Biomed Central 